\title{
Aquatic macrophyte and macroinvertebrate diversity and conservation in wetlands of the Sinos River basin
}

\author{
Maltchik, L. *, Rolon, AS. and Stenert, C. \\ Laboratório de Ecologia e Conservação de Ecossistemas Aquáticos - LECEA, \\ Universidade do Vale do Rio dos Sinos - Unisinos, Av. Unisinos, 950-B, Cristo Rei, \\ CEP 93022-000, São Leopoldo, RS, Brazil \\ *e-mail: maltchik@unisinos.br
}

Received February 21, 2010 - Accepted April 29, 2010 - Distributed December 31, 2010

(With 1 figure)

\begin{abstract}
Wetlands are important sites for biological conservation because they support rich biodiversity and present high productivity. Species-area relationship is an important tool in conservation planning and it has been extensively used for wetland management. This study had as aims: (1) to analyse macrophyte and macroinvertebrate diversity in the fragmented wetlands of the Sinos River basin; and (2) to investigate whether wetland areas could work as a tool for selecting the important habitats for biodiversity conservation. Throughout the study, 56 species of macrophytes and 57 taxa of macroinvertebrates were identified. Macrophyte richness was related to the wetland area, but macroinvertebrate richness, however, was not related to the wetland area. The macrophyte and macroinvertebrate composition were not related to the wetland area. Species composition varied between the regions of the basin and the difference in the species composition occurred mainly by the distribution of macroinvertebrates. With regard to the biodiversity conservation of the Sinos River basin, the wetland area must not be a priority criterion for choosing the important wetlands for conservation. The environmental policies for biodiversity conservation must include management actions focused also on the protection of small wetlands. Moreover, other criteria should be analysed in further research such as habitat diversity, hydroperiod, geographic distribution and connectivity.
\end{abstract}

Keyword: area, diversity, composition, conservation, Neotropical region.

\section{Diversidade e conservação de macrófitas e macroinvertebrados aquáticos em áreas úmidas da bacia do Rio dos Sinos}

\section{Resumo}

As áreas úmidas são locais importantes para a conservação da biodiversidade, pois suportam uma alta diversidade de espécies e alta produtividade. A relação espécie- área é uma ferramenta importante em planos de conservação e amplamente utilizada no manejo de áreas úmidas. Este estudo teve como objetivos: (1) analisar a diversidade de macrófitas aquáticas e macroinvertebrados em áreas úmidas fragmentadas da bacia do rio dos Sinos; e (2) investigar se o tamanho da área úmida é um critério válido para selecionar locais importantes para a conservação da biodiversidade. Ao longo do estudo, foram identificadas 56 espécies de macrófitas aquáticas e 57 taxas de macroinvertebrados. A riqueza de macrófitas esteve relacionada com o tamanho da área úmida, porém, a riqueza de macroinvertebrados não esteve associada ao tamanho da área úmida. A composição de macrófitas e macroinvertebrados não esteve relacionada ao tamanho dos sistemas. A composição de espécies variou entre as regiões da bacia hidrográfica e a diferença na composição ocorreu principalmente devido à distribuição dos macroinvertebrados. Em relação à conservação da biodiversidade na bacia do rio dos Sinos, o tamanho da área úmida não deve ser o critério prioritário para a seleção de locais importantes para a conservação. A política ambiental para a conservação da biodiversidade deve incluir ações de manejo focadas também na proteção de áreas úmidas pequenas. Além disso, outros critérios devem ser avaliados, tais como, diversidade de hábitats, hidroperíodo, distribuição geográfica e conectividade.

Palavras-chave: área, diversidade, composição, conservação, região neotropical. 


\section{Introduction}

Wetlands are important sites for biological conservation because they support a rich biodiversity and present high productivity (Mitsch and Gosselink, 2000). However, biodiversity in wetlands has been reduced worldwide (Shine and Klemm, 1999) - there has been a loss of more than $50 \%$ of these ecosystems in the last century due to agricultural, industrial and urban development (Shine and Klemm, 1999). In Europe, the situation is critical with the loss of almost 2/3 of wetlands by the beginning of the $20^{\text {th }}$ century (Santamaría and Klaassen, 2002). The impact of wetland loss on biodiversity was verified by the decline of populations of several wetland-dependent species (Millennium Ecosystem Assessment, 2005). The rapid degradation of wetlands and the insufficient status of scientific knowledge on patterns of species richness in such systems bring the urgent need for ecological studies to provide scientific support to management and conservation programs of biodiversity.

South America possesses a diversified range of wetlands, from large rivers to small intermittent streams, many of them characterised by the existence of large wetlands (Neiff, 2001). Approximately $95 \%$ of the inventoried wetlands in South America belong to six countries, and Brazil has half of the total wetland area (Naranjo, 1995). Subtropical and tropical wetlands have come under increasing pressure since the 1950s, and the wetland loss in South America over the 90 's was estimated at $6 \%$ of total wetlands of the continent (OECD, 1996). Conservative data indicate that approximately $90 \%$ of the wetlands in Southern Brazil have disappeared in the last century. This is a consequence of a strong habitat fragmentation due to agricultural and urban expansion. Accordingly, the understanding of species composition and richness patterns in fragmented and natural wetlands is a priority for biodiversity conservation strategies and land/water management in Southern Brazil.

Species-area relationship is an important tool in conservation planning and it has been extensively used for wetland management (Gibbs, 2000). The principle that a large area supports more species (Rosenzweig, 1995) has been put into practice in conservation planning. The species-area relationships have also been applied to wetland conservation programs in Southern Brazil, mainly for wetlands fragmented by rice cultivation expansion (Guadagnin et al., 2005; Rolon and Maltchik, 2006; Guadagnin and Maltchik, 2007; Panatta et al., 2007; Stenert and Maltchik, 2007; Rolon et al., 2008; Stenert et al., 2008). However, little has been done for wetlands drained by the urban expansion in basins of high demographic density.

The Sinos River basin is one of the main basins of Rio Grande do Sul State due to the high number of inhabitants - approximately 1.6 million people - that represents $17 \%$ of the state. This basin concentrates the greatest part of the economic growth of the state $(17.32 \%)$, especially shoe-leather, and mechanical and petrochemical sectors (COMITESINOS, 2000). The impact of urban development on the drainage of the wetlands is little known. Therefore, the knowledge of wetland biodiversity in the Sinos River basin and the capacity to identify wetlands of high biodiversity based on species-area relationship are extremely important for conservation biology. In wetlands, a positive relationship between macrophyte and macroinvertebrate richness and area has been found (Heino, 2000; Oertli et al., 2002; Rolon and Maltchik, 2006; Stenert and Maltchik, 2007; Studinski and Grubbs, 2007; Rolon et al., 2008). Consequently, this study had as aims: (1) to analyse the diversity of macrophytes and macroinvertebrates in the fragmented wetlands of the Sinos River basin; and (2) to investigate whether the influence of the area on the richness and on the composition of macrophyte and aquatic macroinvertebrates could work as a tool for selecting the important habitats for the conservation of aquatic biodiversity.

\section{Study Area}

The Sinos River basin is located at the northeastern part of Rio Grande do Sul State, between the geographic coordinates latitude $29^{\circ} 20^{\prime} \mathrm{S}$ and $30^{\circ} 10^{\prime} \mathrm{S}$ and longitude $50^{\circ} 15^{\prime} \mathrm{W}$ and $51^{\circ} 20^{\prime} \mathrm{W}$. It presents an area of approximately $4,000 \mathrm{~km}^{2}$ and is inserted in the Lake Guaíba basin. The Sinos River is $190 \mathrm{~km}$ long, its spring is at $900 \mathrm{~m}$ in the Serra Geral Upland and disembogues into the delta of Jacuí River, $5 \mathrm{~m}$ above sea level. The climate of the region is humid subtropical, and the annual precipitation of the River Sinos basin varies between 1,200 and 2,000 mm.

The Sinos River basin has approximately 1.6 million inhabitants and most of the state's economic production is concentrated there (17.32\%), especially shoe-leather manufacturing, and the mechanical and petrochemical sectors (COMITESINOS, 2000). The impact of urban development on the basin is expressive; the vegetation coverage has been considerably reduced to $10 \%$ of its former area.

The Sinos River basin is comprised of two classes of wetlands distributed over its 32 municipalities. The most expressive wetlands are permanent and intermittent ponds, palustrine wetlands, oxbow lakes, rivers and streams. The quality of the water of the Sinos River basin varies along its longitudinal axis; at its superior and middle regions, the quality is good, while the inferior region is compromised of the input of polluting agents from swage and domestic and industrial residues (COMITESINOS, 2000).

\section{Material and Methods}

A total of 24 wetlands were sampled in 19 municipalities of the Sinos River basin (Figure 1). One single sampling was carried out in each wetland between August and November, 2001. The data sampling was carried in two types of wetlands (ponds and palustrine wetlands) due to the predominance of such systems in the basin.

Aquatic vegetation surveys were performed by visual search sampling methods (collection of plants within a certain area for qualitative analysis) (Convention on Biological Diversity, 2003). A baseline for setting up transects was established after walking through the wetland to evaluate 


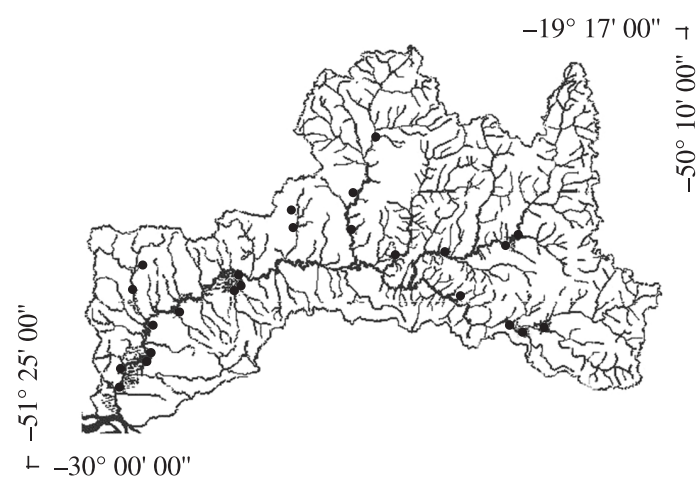

Figure 1. Study area in Sinos River basin in Southern Brazil. A total of 24 wetlands was sampled.

the structure, composition and variability of the aquatic vegetation. The number, extension and position of transects varied depending on wetland size and environmental heterogeneity (water depth and distance between opposite shores). In each wetland, 60-120 minutes were taken to record and collect aquatic macrophytes for subsequent identification. Sampling effort was proportional to the wetland size, in order to capture all aquatic macrophytes present and get the best picture of total richness and composition. An equal sampling effort, on the other hand, would lead to a measure of species density rather than species richness, which would be inappropriate for theoretical purposes (Gotelli and Colwell, 2001). We used the broad definition of aquatic macrophyte, which include submerged, floating and emergent plants (herbs, shrubs and trees) and cover a wide taxonomic range (charophytes, bryophytes, pteridophytes and spermatophytes).

The samplings of macroinvertebrates were carried out using kick net ( $30 \mathrm{~cm}$ width, $250-\mu \mathrm{m}$ mesh). The time taken for macroinvertebrate sampling was proportional to the wetland area (10-45 minutes). Time variation was related to the displacement in the wetlands to show several habitats of the littoral zone (debris, rooted macrophytes and distinct types of dominant vegetation). The net was scarped horizontally along the wetland bottom, and the contents of the sweeps were pooled into one composite sample per wetland (3.5-L plastic bucket) and preserved in situ with $10 \%$ formaldehyde. In the laboratory, each composite sample was washed through $0.42 \mathrm{~mm}$ mesh to remove leaves, stems, and other woody detritus. A sub-sample $(500 \mathrm{~mL})$ was taken from each sample and sorted under a stereomicroscope. The organisms found were kept in glass tubes with $70 \%$ alcohol. Taxonomic identification was performed using Merritt and Cummins (1996), Lopretto and Tell (1995), and Usinger (1963) at the following levels: class, group, order, sub-order, family and genus (for some).

The richness of aquatic macrophytes represents the number of species and the richness of macroinvertebrates was represented by the number of morphospecies found at each sampling point. The criteria used to differentiate the morphospecies were based on the morphological aspects of the individuals, not considering the differences arising from the life cycle of the macroinvertebrates. The geographic location was performed using a GPS device (Personal Navigator GPS III Plus). The relationship between wetland area and the richness of macrophytes and macroinvertebrates was calculated through the linear regression. The differences in the richness of macrophytes and macroinvertebrates between the inferior, middle and superior regions basin were compared using the ANOVA.

The composition of macrophytes and macroinvertebrates was analysed using Detrended Correspondence Analysis - DCA (Hill and Gauch, 1980) in PC-ORD Version 4.2 (McCune and Mefford, 1999). In the ordination analysis, the wetlands were classified according to the region of the basin (superior, middle, and inferior) in order to highlight possible differences in the spatial succession of the aquatic species. Ordination was performed using the macrophyte and macroinvertebrate presence/absence, including in the analysis only the taxa that occurred in more than $10 \%$ of wetlands. The relationship between the wetland area and the composition of macrophytes and aquatic macroinvertebrates was calculated through a linear regression, using the first two axes of ordination.

The differences between the regions (superior, middle and inferior) on species composition were verified by MRPP (Multi-Response Permutation Procedures) (PC-ORD 4.0, McCune and Mefford, 1999). An Indicator Species Analysis (Dufrene and Legendre, 1997) was used to determine which species discriminated the different regions. The significance of the discriminating power was determined by the Monte-Carlo test (5000 permutations).

\section{Results}

Throughout the study, 56 species of macrophytes were identified as well as 57 taxa of macroinvertebrates. The aquatic macrophytes have represented 43 genera and 27 families. The families with the highest number of representatives were Asteraceae and Cyperaceae. The most frequent species of aquatic macrophyte were: Ludwigia peploides (75\% of the wetlands); Polygonum hydropiperoides (75\%); Luziola peruviana (67\%); Hydrocotyle ranunculoides (54\%), and Eleocharis sellowiana (50\%). The majority of species $(60.7 \%)$ was found in less than $10 \%$ of the wetlands.

The 57 taxa of macroinvertebrates were identified at different taxonomic levels: 47 taxa at the family level, one at the sub-order level, three at the order level, one at the group level, and five at the class level. Among them, 41 taxa belonged to the class Insecta $(71.9 \%)$, presenting individuals under different stages of the life cycle. Among the total of aquatic insects, $57.1 \%$ needed an aquatic habitat for the development of their juvenile stages of life. The rest $(42.9 \%)$ depended on this habitat for the complete development of the life cycle. The highest number of families sampled belonged to the order Diptera (13 families) and Coleoptera (9 families). Some genera of Coleoptera were identified such: Tropisternus, Berosus and Hydrophilus (Hydrophilidae), Megadytes (Dytiscidae); Ephemeroptera: 
Baetis (Baetidae), Caenis (Caenidae); Trichoptera: Oecetis (Leptoceridae) and Oxyethira (Hydroptilidae); Hemiptera: Belostoma (Belostomatidae); and the class Hirudinea: Helobdella and Haementeria (Glossiphoniidae). The families of the most frequent aquatic insects were: Chironomidae (87.5\%), Dytiscidae (79.1\%), Hydrophilidae (79.1\%), Belostomatidae (75\%), and Libellulidae (75\%). Among the crustaceans, annelids, and molluscs, the most frequent families were: Cyclopidae (75\%), Glossiphoniidae (75\%), and Planorbidae (75\%). The classes Oligochaeta and Bivalvia were also frequent at the wetlands (79.1 and $79.1 \%$, respectively).

Macrophyte richness was related to the wetland area $\left(\mathrm{R}^{2}=0.442, \mathrm{p}=0.031\right)$. However, macroinvertebrate richness was not related to the wetland area $\left(R^{2}=0.022\right.$; $\mathrm{p}=0.883$ ). Macrophyte and macroinvertebrate richness did not vary significantly along the basin region $(\mathrm{F}=0.665$, $\mathrm{p}=0.583 ; \mathrm{F}=1.124 ; \mathrm{p}=0.344$, respectively).

Based on the DCA ordination, the first and the second axes of DCA explained $32 \%$ of the variance in the species composition (13 and 9\%, respectively). Regarding the macrophyte and macroinvertebrate composition, the sample scores were not related to the wetland area (DCA1 $\mathrm{F}=1.272 ; \mathrm{p}=0.272$ and DCA2 $\mathrm{F}=0.045 ; \mathrm{p}=0.835$ ). The species composition varied between the portions of the basin $(\mathrm{A}=0.032, \mathrm{p}=0.004)$. The difference in the species composition between the regions of the Sinos River occurred mainly by the distribution of macroinvertebrates. The families Chironomidae, Ceratopogonidae, Cyclopidae, Tabanidae, Aeshnidae, Libellulidae, and Glossiphoniidae have characterised the wetlands of the middle portion of the basin $(\mathrm{p}<0.05)$. The wetlands of the inferior region were characterised by the presence of the family Chaoboridae and by the floating macrophyte species Salvinia herzogii $(\mathrm{p}<0.05)$. The superior portion was not characterised by any taxon.

\section{Discussion}

The diversity of aquatic macrophytes found in the Sinos River basin (57 species) may be considered high, especially when we compared it with other studies carried out in the wetlands of Southern Brazil (250 species) (Rolon et al., 2004, 2008). Furthermore, the number of species found in the Sinos River basin has represented around $10 \%$ of the total aquatic macrophyte diversity estimated for Rio Grande do Sul State (Irgang and Gastal, 1996). Such high value found in Rio Grande do Sul State is due to the high spatial scale studied by these researchers and by high numbers of classes of wetlands analysed - e.g. estuarine and coastal wetlands. However, the community of aquatic macrophytes in the wetlands of the basin was represented by several biological forms (submerged, floating, emergent and amphibious). Emergent species dominated the wetlands, and the families Asteraceae and Cyperaceae were outstanding with regard to the number of species.

The diversity of macroinvertebrates found in the wetlands of the Sinos River basin was similar to other surveys of macroinvertebrates carried out in South America (Bendati et al., 1998; Marques et al., 1999; Barbosa and Callisto, 2000). In the River Sinos basin, the community of invertebrates was mainly represented by taxa belonging to the class Insecta $(71.9 \%)$. Such great representation is due, mainly, to the morphological and physiological adaptations of these organisms such as the resistance of the eggs, the varied diet under the different life stages, the presence of wings - which make dispersion easy - the access to food and escape from predators (Ruppert and Barnes, 1996).

The biogeographical principle that a larger area supports more species has been put into practice in applied fields of conservation biology (Primack, 1998). The conservation of wetlands based on its size has been a criterion analysed in the literature (Gibbs, 2000; Snodgrass et al., 2000). Several studies have already highlighted the importance of small wetlands for the conservation of biodiversity (Semlitsch and Bodie, 1998; Russel et al., 2002). The positive relationship between area and macrophyte and macroinvertebrate richness has been found in Southern Brazil wetlands (Rolon and Maltchik, 2006; Stenert and Maltchik, 2007; Rolon et al., 2008). However, for the macroinvertebrate community, the influence of the area is controversial (Panatta et al., 2007; Stenert et al., 2008). In the Sinos River basin, wetland area influenced macrophyte richness. However, macroinvertebrate richness was not related to wetland area. The biogeographical principle has limitations regarding macroinvertebrate fauna because distinct taxonomic groups show different trends, while the richness of crustaceans (Fryer, 1985), snails (Lassen, 1975; Aho, 1978; Brönmark, 1985), and Odonata (Oertli et al., 2002) tended to increase with the wetland area. In other studies, this relationship was not significant for Sphaeriidae and Coleoptera, and also for the macroinvertebrate community (Oertli et al., 2002; Brose, 2003; Batzer et al., 2004; Hall et al., 2004). These different results show that the species-area relationship is not always consistent for wetland macroinvertebrates, explaining, in part, the lack of significant relationship between area and macroinvertebrate richness in the present study. Such results demonstrate that, unlike for aquatic macrophytes, the area is not a valid criterion for identifying the areas with high diversity of macroinvertebrates in the Sinos River basin, since several small wetlands have presented high macroinvertebrate diversity. Even so, several studies have highlighted that the wetland area may be a useful tool for choosing the priority areas for conservation; nevertheless, such a premise must not be the only tool to be applied when determining the conservation of the wetlands of the Sinos River basin. In the set of wetlands studied, the small ones also played an important role for the regional species diversity, including that of the aquatic macrophytes where the species-area relationship was found.

The composition of the species was not determined by the wetland area, although other studies identified the influence of the area on macrophyte and macroinvertebrate composition (Heegaard et al., 2001; Stenert and Maltchik, 
2007; Rolon et al., 2008). The difference in the composition of the species between the portions of the basin occurred mainly due to the distribution of the families of macroinvertebrates along the wetlands. The occurrence of some macroinvertebrate taxa (Chironomidae, Ceratopogonidae, Cyclopidae, Tabanidae, Aeshnidae, Libellulidae, and Glossiphoniidae) was associated to the wetland of the middle region of the basin. The species of aquatic macrophytes were not associated with the portion of the basin, excepting the species Salvinia herzogii, which was frequent at the inferior region.

Our results have identified high diversity of macrophytes and macroinvertebrates in the Sinos River basin and such diversity is high even at the inferior portion of the basin, where the quality of the water was compromised (COMITESINOS, 2000). With regard to the conservation of the biodiversity of the Sinos River basin, the area must not be a priority criterion for choosing the important wetlands for conservation. The environmental policies for biodiversity conservation must include management actions focused also on the protection of small wetlands. Furthermore, other criteria must be analysed in further research such as habitat diversity, hydroperiod, geographic distribution and connectivity.

\section{References}

AHO, J., 1978. Freshwater snail populations and the theory of island biogeography: A case study in southern Finland. Annales Zoologici Fennici, vol. 15, no.1-4, p. 146-154.

BARBOSA, FAR. and CALLISTO, M., 2000. Rapid assessment of water quality and diversity of benthic macroinvertebrates in upper and middle Paraguay River using the Aqua-Rap approach. Verhangen International Verein Limnology, vol. 27, no. 5, p. 2688-2692.

BATZER, DP., PALIK, BJ. and BUECH, R., 2004. Relationships between environmental characteristics and macroinvertebrate communities in seasonal woodland ponds of Minnesota. Journal of the North American Benthological Society, vol. 23, no. 1, p. 50-68.

BENDATI, MMA., MAIZONAVE, CRM., OLABARRIAGA, ED. and ROSADO, RM., 1998. Use of the benthic macroinvertebrate community as a pollution indicator in the Gravataí River (RS, Brazil). International Vereinigung fur Theoretische und Angewandte Limnologie, vol. 26, no. 4, p. 2019-2023.

BRÖNMARK, C., 1985. Freshwater snail diversity: effects of pond area, habitat heterogeneity and isolation. Oecologia, vol. 67, no. 1, p. 127-131.

BROSE, U., 2003. Island biogeography of temporary wetland carabid beetle communities. Journal of Biogeography, vol. 30, no. 6 , p. 879-888.

Comitê de Gerenciamento da Bacia Hidrográfica do Rio dos Sinos - COMITESINOS, 2000. Enquadramento das águas da Bacia Hidrográfica do Rio dos Sinos. São Leopoldo: Impresul, 16 p.

Convention on Biological Diversity, 2003. Report of the expert meeting on methods and guidelines for the rapid assessment of biological diversity of inland water ecosystems. In Eighth Meeting of the Conference of the Parties to the Convention on Biological
Diversity, March 10-14, 2003. Montreal, CA. Available from: $<$ http://www.biodiv.org/doc/meetings/sbstta/sbstta-08/information/ sbstta-08-inf-05-en.pdf>.

DUFRENE, M. and LEGENDRE, P., 1997. Species assemblages and indicator species: the need for a flexible asymmetrical approach. Ecological Monographs, vol. 67, no. 3, p. 345-366.

FRYER, G., 1985. Crustacean diversity in relation to the size of water bodies: some facts and problems. Freshwater Biology, vol. 15 , no. 3, p. 347-361.

GIBBS, JP., 2000. Wetland loss and biodiversity conservation. Conservation Biology, vol. 14, no. 1, p. 314-317.

GOTELLI, NJ. and COLWELL, RK., 2001. Quantifying biodiversity: procedures and pitfalls in the measurement and comparison of species richness. Ecology Letters, vol. 4, no. 4, p. 379-391.

GUADAGNIN, D. and MALTCHIK, L., 2007. Habitat and landscape factors associated with Neotropical waterbird occurrence and richness in wetland fragments. Biodiversity and Conservation, vol. 16, no. 4, p. 1231-1244.

GUADAGNIN, DL., PETER, AS., PERELLO, LFC. and MALTCHIK, L., 2005. Spatial and temporal patterns of waterbird assemblages in fragmented wetlands of southern Brazil. Waterbirds, vol. 28, no. 3, p. 261-272.

HALL, DL., WILLIG, MR., MOORHEAD, DL., SITES, RW., FISH, EB. and MOLLHAGEN, TR., 2004. Aquatic macroinvertebrate diversity of playa wetlands: the role of landscape and island biogeographic characteristics. Wetlands, vol. 24, no. 1, p. 77-91.

HEEGAARD, E., BIRKS, HH., GIBSON, CE., SMITH SJ. and WOLFE-MURPHY, S., 2001. Species-environmental relationship of aquatic macrophytes in Northen Ireland. Aquatic Botany, vol. 70 , no. 3 , p. $175-223$.

HEINO, J., 2000. Lentic macroinvertebrate assemblage structure along gradients in spatial heterogeneity, habitat size and water chemistry. Hydrobiologia, vol. 418, no. 1, p. 229-242.

HILL, MO. and GAUCH, HG., 1980. Detrended correspondence analysis: an improved ordination technique. Plant Ecology, vol. 42 , no. $1-3$, p. $47-58$.

IRGANG, BE. and GASTAL Jr., CVS., 1996. Macrófitas aquáticas da planície costeira do RS. Porto Alegre, $290 \mathrm{p}$.

LASSEN, HH., 1975. The diversity of freshwater snails in view of the equilibrium theory of island biogeography. Oecologia, vol. 19 , no. 1 , p. 1-8.

LOPRETTO, EC. and TELL, G., 1995. Ecosistemas de Aguas Continentales. Metodologia para su estudio. La Plata: Ediciones Sur, Tomo III, 1401 p.

MARQUES, MMGSM., BARBOSA, FAR. and CALLISTO, M., 1999. Distribution and abundance of Chironomidae (Diptera, Insecta) in an impacted watershed in south-east Brazil. Revista Brasileira de Biologia, vol. 59, no. 4, p. 553-561.

MCCUNE, B. and MEFFORD, MJ., 1999. PC-ORD. Multivariate Analysis of Ecological Data. Version 4. Gleneden Beach, OR, US: MJM Software Design.

MERRIT, R. and CUMMINS, KW., 1996. An Introduction to the Aquatic Insects of North America. Iowa: Kendall/Hunt Publishing Company, $862 \mathrm{p}$. 
Millennium Ecosystem Assessment, 2005. Ecosystems and human well-being: wetlands and water. Washington: World Resources Institute, $80 \mathrm{p}$.

MITSCH, WJ. and GOSSELINK, JG., 2000. Wetlands. New York: John Wiley and Sons, 920 p.

NARANJO, LG., 1995. An evaluation of the first inventory of South American wetlands. Vegetatio, vol. 118, no. 1-2, p. 125-129.

NEIFF, JJ., 2001. Diversity in some tropical wetland systems of South America. In GOPAL, B., JUNK, WJ. and DAVIS, JA. (Eds.). Biodiversity in wetlands: assessment, function and conservation. Leiden: Backhuys Publishers, p. 157-186.

OERTLI, B., JOEY, DA., CASTELLA, E., JUGE, R., CAMBIN, D. and LACHAVANNE, JB., 2002. Does size matter? The relationship between pond area and biodiversity. Biological Conservation, vol. 104, no. 1, p. 59-70.

Organization for Economic Co-operation and Development - OECD, 1996. Guidelines for aid agencies for improved conservation and sustainable use of tropical and subtropical wetlands. Paris: OECD.

PANATTA, A., STENERT, C., SANTOS, EM., and MALTCHIK, L., 2007. Diversity and distribution of chironomid larvae in wetlands in southern Brazil. Journal of the Kansas Entomological Society, vol. 80 , no. 3, p. 229-242.

PRIMACK, RB. 1998. Essentials of Conservation Biology. Sunderland: Sunauer Associates, 564 p.

ROLON, AS. and MALTCHIK, L., 2006. Environmental factors as predictors of aquatic macrophyte richness and composition in wetlands of Southern Brazil. Hydrobiologia, vol. 556, no. 1, p. 221-231.

ROLON, AS., LACERDA, T., MALTCHIK, L. and GUADAGNIN, DL., 2008. The influence of area, habitat and water chemistry on richness and composition of macrophyte assemblages in southern Brazil wetlands. Journal of Vegetation Science, vol. 19, no. 2, p. 221-228.

ROLON, AS., MALTCHIK, L. and IRGANG, B., 2004. Levantamento de macrófitas aquáticas em áreas úmidas do Rio Grande do Sul, Brasil. Acta Biologica Leopoldensia, vol. 26, no. 1, p. 17-35.
ROSENZWEIG, ML., 1995. Species diversity in space and time. Cambridge: Cambridge University Press, 460 p.

RUPPERT, EE. and BARNES, DR., 1996. Zoologia dos Invertebrados. São Paulo: Rocca, 1029 p.

RUSSEL, KR., GUYNN, DC. and HANLIN, HG., 2002. Importance of small isolated wetlands for herpetofaunal diversity in managed, young growth forests in the Coastal Plain of South Carolina. Forest Ecology and Management, vol. 163, no. 1-3, p. 43-59.

SANTAMARÍA, L. and KLAASSEN, M., 2002. Waterbirdmediated dispersal of aquatic organisms: An introduction. Acta Oecologica, vol. 23, no. 3, p. 115-119.

SEMLITSCH, RD. and BODIE, JR., 1998. Are small, isolated wetlands expendable? Conservation Biology, vol. 12, no. 5, p. 1129-1133.

SHINE, C. and KLEMM, C., 1999. Wetlands, water and the law: Using law to advance wetland conservation and wise use. Gland: IUCN, 348 p.

SNODGRASS, JW., KOMOROSKI, MJ., LAWRENCE BRYAN, A. and BURGER, J., 2000. Relationships among isolated wetland size, hydroperiod, and amphibian species implications for wetland regulation. Conservation Biology, vol. 14, no. 2, p. 414-419.

STENERT, C. and MALTCHIK, L., 2007. Influence of area, altitude and hydroperiod on macroinvertebrate communities in southern Brazil wetlands. Marine and Freshwater Research, vol. 58 , no. 11, p. 993-1001.

STENERT, C., BACCA, RC., MOSTARDEIRO, CC. and MALTCHIK, L., 2008. Environmental predictors of macroinvertebrate communities in coastal wetlands of southern Brazil. Marine and Freshwater Research, vol. 59, no. 6, p. 540-548.

STUDINSKI, JM. and GRUBBS, SA., 2007. Environmental factors affecting the distribution of aquatic invertebrates in temporary ponds in Mammoth Cave National Park, Kentucky, USA. Hydrobiologia, vol. 575, no. 1, p. 211-220.

USINGER, RL., 1963. Aquatic Insects of California with keys to North American genera and California species. Berkeley: California University Press, 508 p. 